\title{
Profile of Crack Users in Detoxification Process in Therapeutic Communities from Paraíba
}

\begin{abstract}
Poliana Rafaela dos Santos Araújo1, Gabriel Chaves Neto², Mateus Feitosa Alves ${ }^{3}$, Flávia Maiele Pedrosa Trajano ${ }^{4}$, Leidyanny Barbosa de Medeiros, Laysa Karen Soares de Lima ${ }^{6}$, Humberto Hugo Nunes de Andrade ${ }^{6}$, Margareth de Fátima Formiga Melo Diniz" João Euclides Fernandes Braga ${ }^{8}$
\end{abstract}

\section{Abstract}

Objective: This study traces the profile of crack users interned in therapeutic communities in Paraiba.

Methods: A descriptive study with a quantitative approach, developed with 20 volunteers. The data collection was conducted through semi structured interview and Anxiety Trace-State Inventory (IDATE-T).

Results: The therapeutic communities' crack users are predominantly young adults, single, brown, having completed high school, motivated to use the drug due to desire/curiosity for the drugs' effects. First crack consumption from 10 to 19 years old, period using ranges from 1 to 5 years with daily use with the average of more than 21 stones. Multiple users with high anxiety who work regularly and tried to abandon the crack, $55 \%$ of them lived on the streets and $65 \%$ presented suicide thought.

Conclusions: The study gives parameters to the assistance of the dependents, highlighting the importance of research in therapeutic communities.

\section{Keywords}

Crack Cocaine; Drug Users; Therapeutic Community
1 Nurse. Member of the Research and Extension for Synapse and Anxiety Group, CCS/UFPB. Universidade Federal da Paraiba,

2 Nurse. Technological Development and Inovation in Medicines Program PhD Student, PPGDITM/UFPB; Master in Cognitive Neuroscience Behavior; Member of the Research and Extension for Synapse and Anxiety Group. Universidade Federal da Paraiba, ${ }^{*}$

3 Pharmaceutic. PhD Student in Natural and Synthetic Bioactive Products, PgPNSB/UFPB; Master in Natural and Synthetic Bioactive Products. PgPNSB/ UFPB. Universidade Federal da Paraiba, ${ }^{*}$

4 Nurse. PhD student by Postgraduate Program in Decision Models in Health, PPGMDS/UFPB; Master in Cognitive Neuroscience Behavior, PPGNeCl UFPB; Member of the Research and Extension for Synapse and Anxiety Group. CCS/UFPB. Universidade Federal da Paraiba, ${ }^{*}$

5 Nurse. Master in Decision Models in Health - PPGMDS/UFPB. Universidade Federal da Paraiba, ${ }^{*}$.

6 Nursing student at UFPB; Member of the Research and Extension for Synapse and Anxiety Group, CCS/UFPB. Universidade Federal da Paraiba, ${ }^{*}$

7 Pharmacist; PhD Professor in the Pharmaceutical Science Department; Universidade Federal da Paraiba; ${ }^{*}$.

8 Nurse. PhD Professor in the Nursing and Public Health Department; Universidade Federal da Paraiba; Coordinator of the Research and Extension for Synapse and Anxiety Group, CCS/UFPB. *.

Contact information:

\section{Gabriel Chaves Neto}

” gabrielchavesufpb@hotmail.com 


\section{Introduction}

The use of psychoactive substances throughout the years is becoming a world problem attributed to the cultural and social changes imposed by the globalization. The people who search for ways to relieve suffering and to escape from reality find drugs as refuge. Among the drugs, crack stands out for its low cost, form of action and potential dependence [1].

The crack is a form of cocaine, produced by the mixture of the drug and sodium bicarbonate, forming stones that are posteriorly smoked with a pipe. The inhalation of the smoke has a quick action on the central nervous system causing the sensation of satiety and pleasure, with limited effect however. Another characteristic presented is its high dependence potential, causing an uncontrollable desire for consumption, known as craving [2].

Brazil is the developing country with the largest market for crack in South America, with wide dissemination throughout its territory, increasing the State's concern regarding public health. The health professionals and researchers are highly interested in searching for ways of treatment for the dependents, aiming to delay the damage caused to the mental, physical and social life [3].

Crack users have difficulties searching for strategies and dependence treatment services, because of the absence of therapeutic plans adapted to each individual's necessity3. The use of medicine (antidepressant, dopaminergic agonists and antipsychotics) has not presented satisfactory therapeutic results as isolated therapeutic intervention on drug addiction abandonment [4].

The occurrence of psychiatric disorders in chemical dependents is common and hampers the detoxification process, making necessary the early tracking for the development of a strategy that focuses on abandonment and prevention of relapses. Among the disorders, the anxiety is present and is accentuated before the life experiences that the drug users face, such as involvement in crimes, fa- mily and social problems, mourning for friends or even for when they are in abstinence $[5,6]$.

Before the lack of public policies turned to the crack users and the inefficiency of the State with qualified services for this specific society group, the therapeutic communities emerge, created as a proposition for treatment of chemical dependents [7].

The therapeutic community is a physical space where a number of people who present chemical dependence as a common characteristic are inserted. It can also be recognized as a micro-society kept by its inmates' work through the division of tasks. Regarding the organizational environment, there is a leader responsible for the maintenance of the rules of behavior [8]. As for the therapeutic environment, it is governed by a hospitalization period prioritizing self-motivation, with limited emphasis in the clinic. It is permitted the participation of the individual in their recovery process as a way to encourage their daily achievements. There are still as requirements to the residents: discipline to keep away from alcohol and others drugs; work so they can feel responsible for something; and moments of praying so that they could have faith as a strengthener for the treatment [9].

The religion as a form of support has a large influence on the way that the inmate deals with the drug abandonment process, being an essential point to the recovery and one that must be reinvigorated daily. Expressing faith involves the individual as a whole, encompassing both physical and mental parts, while it transmits comfort and hope, and prevents self-destructive actions such as the use of chemical substances [10].

The dynamic of operation of the therapeutic communities is target of critics, for necessitating a closed environment for the development and utilization of religion as a recovery tool. Authors affirm that it is a lack of respect to the liberty of faith and interferes with the right of free will, resulting in a break of the ties of the individual with what governs society, furthermore many communities work pre- 
cariously and there is the administration of medicine without medical prescription [11].

According to the therapeutic communities census in Brazil conducted in 2015 by the National Secretariat of Drugs Policies (Secretaria Nacional de Políticas sobre Drogas - SENAD), from the Justice Ministry, there are 1623 registered therapeutic communities in operation. However, most of the communities do not present a regulatory record, setting up a problem for the control of the dependents coverage, as well as not being known exactly about their implications on the users' lives [8].

Considering the chemical dependence problem and the therapeutic communities' role on the users' rehab process, the study achieved the objective of tracing the profile of the inmate crack users in two therapeutic communities in Paraiba, taking into account the socio demographic characteristics, the characterization of drug addiction and the anxiety level.

\section{Method}

It is a descriptive study with a quantitative approach, developed with inmate crack users in abstinence. The study was conducted in two therapeutic communities for chemical dependents in Paraiba, where 75 chemical dependent inmates were attended. The sample was constituted by 20 crack dependents who had been selected according to eligibility criteria: be older than 18 years old, have the crack as the drug reason of rehab and acceptance to the study participation by signing the Term of Consent.

For data collection, a semi-structured interview for the volunteers' socio demographic characterization was used, through a specific questionnaire, identifying variables such as gender, age, and crack consumption aspects.

To measure the profile of anxiety of volunteers, it was applied the State-Trait Anxiety Inventory (STAI), using the subscale ASI-T (Trait Anxiety Inventory), elaborated by Spielberger, Gorsuch and Lushene
[12] in 1970, translated and validated to Portuguese by Biaggio and Natalício13 in 1979. The ASI-T measures the individual's anxiety trait, differentiating the tendency to react to situations identified as threatening, being a more stable characteristic during the life. It is divided in $\mathbf{2 0}$ questions, with four possible level of intensity answers, that vary from 1 to 4 , in which the added scores per each volunteer varies from 20 to 80 points.

The data were collected in individual sessions, in reserved rooms offered by the coordination of the therapeutic organizations. After the user agreed to take part of the research and satisfy the eligibility criteria, it was conducted a brief explanation about the objectives of the study and then the Term of Consents signatures were obtained, after these procedures the semi structured interview begun and after it the ASI-T application.

The data were analyzed through descriptive statistics with the help of the statistical software GraphPadPrism (version 6.00, GraphPad Software Inc., San Diego, CA, USA) and presented in percentages for a better comprehension and discussion of the results.

The study was approved under protocol No. 094/1115. CAAE: 42619715.2.0000.5188 of the Ethics and Research Committee of the Health Sciences Center from Universidade Federal da Paraiba, respecting the resolution No. 466/12 from the National Health Council, which regulates the conduction of researches involving human beings.

\section{Results}

The participants profile according to the socio demographical aspects showed that the majority of the users were young adults, comprising 90\% (18) between 20 and 39 years old, single comprising $90 \%$ (18) of the users, and self-declared brown encompassing 60\% (12) of the individuals. According to the schooling level, $45 \%$ (9) finished high school, and 25\% (5) did not get to finish elementary school. 
According to the characteristics related to crack use, $40 \%$ (8) used it in a period of 1 to 5 years, $45 \%$ (9) begun consumption between 10 to 19 years old and $40 \%$ (8) between 20 to 29 years old; $85 \%$ (17) used crack daily and $40 \%$ (8) smoked more than 21 stones per day. During the period of using crack 55\% (11) got to live on the streets, 65\% (13) thought about suicide and 90\% (18) affirmed to use others drugs (65\% (13) cigars, 55\% (11) alcohol, $55 \%$ (11) cocaine, and 50\% (10) marijuana).

To obtain money to use crack $80 \%$ (16) managed solely through a regular job, $40 \%$ (8) were part of drug dealing and $30 \%$ (6) obtained through regular job as well as illegal actions (robbery, theft, larceny). Regarding the reasons that led to the consumption, $55 \%$ (11) said they felt desire/curiosity and 30\% (6) were motivated by affective losses or family problems. (Table 1)

Table 1. Characterization of Inmate Crack users in therapeutic communities, according to socio demographic data and drug use. Paraiba, Brazil. 2015.

\begin{tabular}{|l|c|c|}
\hline \multicolumn{1}{|c|}{ Variables } & No. & $\%$ \\
\hline Age & & \\
\hline $20-29$ & 09 & 45 \\
\hline $30-39$ & 09 & 45 \\
\hline$\geq 40$ & 02 & 10 \\
\hline Marital Status & & \\
\hline Single & 18 & 90 \\
\hline Divorced & 02 & 10 \\
\hline Consumption Period & & \\
\hline $1-5$ years & 08 & 40 \\
\hline 6-10 years & 05 & 25 \\
\hline $11-15$ years & 05 & 25 \\
\hline 16-20 years & 02 & 10 \\
\hline Consumption Frequency & & \\
\hline Daily & 17 & 85 \\
\hline 1 to 3 days in the week & 02 & 10 \\
\hline 3 to 5 days in the week & 01 & 05 \\
\hline
\end{tabular}

Source: Direta 2015.
According to the period of permanence at the therapeutic community, 65\% (13) of users were inmates from 1 to 6 months. Regarding the abstinence period, 55\% (11) had not been using crack for 1 to 6 months, 90\% (18) had already tried to abandon the drug addiction other times, and 55\% (11) attended some sort of medical service or therapeutic community in others attempts to abandon the drug use $(30 \%(6)$ at the Alcohol and Drugs Psychosocial Center (Centro de Atenção Psicossocial Álcool e Drogas - CAPS AD) and 25\% (5) in another community).

When measured the anxiety trace that is related to personality and evaluated the individual capacity to react to situations considered threatening by them, 70\% (14) of the users presented high anxiety, and only 30\% (6) had low anxiety scores. (Table 2)

Table 2. Classification of inmate crack users in therapeutic communities according to the anxiety-trace level. Paraiba, Brazil. 2015.

\begin{tabular}{|l|c|c|}
\hline \multicolumn{1}{|c|}{ Crack Users Anxiety-Trace } & No. & $\%$ \\
\hline High Anxiety & 14 & 70 \\
\hline Low Anxiety & 6 & 30 \\
\hline & Source: Direta 2015. \\
\hline
\end{tabular}

\section{Discussion}

The study presented similar results to the research conducted by other authors [14], with most of the crack users represented by young adults, single, and with completed Primary and High School. The level of study presented is characterized as historical and social consequence where the youngest and with lowest schooling, who are in detoxification process, have difficulties of access to health service.

Young and single adults represent the therapeutic community inmates. In researches conducted, the crack dependents in detoxification were in average 27 years old and the majority were single $[15,16]$. In a study developed in a national level by Fundação Oswaldo Cruz - Fiocruz in 2014, with crack depen- 
dents, it is presented a profile with the prevalence of young adults having low schooling involved with the drug [17]. The volunteers when self-declaring their skin color characterized the sample as nonwhite, even if in Brazil there is the predominance of the white color compared to brown or black skin colors, revealing the social vulnerability intrinsic to the skin color.

Researchers observed that the individuals with Primary and High School levels have low acquisitive power. However, the fact that involvement with drugs generate debts makes it so it is not possible to expose with clarity their income condition, furthermore the break of family bonds, even if temporary, could categorize the dependent in a different economic class from when they were in the family environment [15].

Data about the crack consumption period from this study reveals that the inmates used daily more than 21 stones from 1 to 5 years when they were between 10-19-years-old. Authors report that the users affirm using it for more than one year, when they were already constitutionally in their adulthood, with the daily consumption of about 10 stones per each drug ministration $[5,14,16]$.

According to the profile of the inmates of the communities, 55\% of them had lived on the streets. In the research developed by FIOCRUZ in 2014, it cannot be affirmed that the users are part of the street population, despite the considerable number of dependents in this situation, approximately $40 \%$ of the sample, which does not mean to say that these were all homeless, but that for the majority of the time they were not at home [17].

In this study, 55\% of the inmates also affirmed to have attended to another service for crack detoxification, such as CAPS AD, another therapeutic community and hospital bed for chemical dependents. Literature reveals that most of the users in detoxification at CAPS AD tried an exclusive treatment there, while a smaller fraction complemented with hospitalization at a psychiatric hospital or therapeutic community [5].
As an alarming data, $65 \%$ of the therapeutic communities' inmates had already presented the thought of suicide. Another study points out that the concern that the dependents try to do something against themselves is present during the recovery process when evaluating that their sample showed high level of suicidal thought. Suicide is considered as a serious problem to public health and is directly linked to mental disorders and drugs, being priority during treatment at the detoxification moment as a high reaction to craving [6].

For having a quick effect, crack is usually consumed with other chemical substances, such as alcohol, cigar, cocaine, marijuana and solvents $[5,15,16]$, as shown in the results of this present study. Others investigations presented data that related crack morbidities to others substances, in which the dependents tend to begin the use with alcohol and cigar, and progress to smoking the stone alongside the others substances, for each used drug the risk to start consuming crack earlier increases [18].

The easy way to get crack and other drugs and its immature consumption, are indicated as precursors to the beginning of consumption5. When the user starts to tolerate the drug's effect it is common to increase the quantity or to combine it with other psychoactive substances that help to soften the symptoms unleashed by the abstinence, which can hide the presence of a higher resistance to the manifestations of abandonment in case only one drug were used [6].

In Brazil, the majority of the dependents affirm to obtain their income through sporadic or independent work, followed by alms, help from friends and family and a relatively low number by participation in illegal activities, showing that the latter is not the main source of income. However many are those who appeal to illegality to satiate the addiction after the indiscriminate use of the income for drug purchasing [17].

Among the occupational characteristics presented in this study, the regular job stands out, followed by drug dealing and illegal activities. In a 
database present in literature it is observed that the unemployed are the majority, followed by a group composed by both independent workers and those who have a formal job, from where the income was took for consumption, as well as belonging acquired through crimes. Due to the most part of them not having a formal job makes it so there is an increase in the level of dependence [16].

The great majority of the users from the communities were motivated by the desire/curiosity in trying the drug's effects, followed by the family problems and affective losses and afterwards by friends' pressure/influence, this shows the importance to invest in preventive measures that highlights the crack detriments to avoid the initial desire for trying out the drug. These data reveal that the low prince is just a factor that facilitates the use in a long term, but it is not the main factor for the beginning of consumption.

According to this present study's data, by making the analysis of the hospitalization time in the community and the time without using crack, it is noticed that few were in abstinence before the hospitalization, even if at any moment in life $90 \%$ had tried to abandon the drug addiction other times.

The difficulty of the chemical dependent to start the treatment and to continue it occurs by the lack of bond creation with the caring institution, which depends exceptionally on the importance that the professional shows to the user, in addition to the correct handling in each case and especially to the craving [5].

In a research conducted in this ambit, the dependents where hospitalized being about 25 years old and with the average of four hospitalizations counting the current one, after four years of contact with crack, showing that it is necessary an approach to the treatment in a way so that the user may develop their resilience avoiding possible further hospitalizations [18].

In the analysis of the results presented in studies in literature, the users tried to interrupt crack use other times with help from some treatment in clinics, therapeutic communities or hospitalization for detoxification. The latter requires a higher attention, due to the users not being able to continue in abstinence after the discharge, requiring an approach aimed at relapse care [16].

In chemical dependents, it is common the existence of psychiatric morbidities that hinders the efficient treatment, making it necessary the early diagnosis of the disorders so that it may be possible to create therapeutic strategies that facilitate the abandonment and prevents possible relapses. It is important to establish the relation between the health services and the professionals in the area with the patient and their family, having as crucial point their cultural, social and economic singularities [5].

Most of the communities' users presented a high anxiety level. A study found the appearance of anxiety symptoms on chemical dependents in abstinence, in which the drug use may be the user's attempt to reduce this symptomatology, or this disorder appearance would be due to the psychoactive substances' effects on the central nervous system, being the second option more accepted due to the drug's direct action in the organism [6].

With a similar analysis, another study reveals the symptomatology occurrence of anxiety in response to the situations in which they are exposed to, such as: involvement with the police or justice, unemployment, commitment in cases of violence, and mainly mourning for friends [14]. Researchers provide literature with results in which the users who presented criminal record developed characteristics related to anxiety, by being exposed to the risk of death by homicide. In addition to that, after one week of abstinence it is possible to notice that a few less than half showed to be anxious, being it a common mental disorder in crack dependents and that it needs special care [16].

The individuals use the drug as a simpler way to attend the necessities and social and familiar demands, being characterized by their social vulnerabi- 
lity. The crack is considered, by the users, as an aid for tension reduction for a short time period, and is effective to slow down the anguish, pain, concerning or any other negative feeling when postponing the confrontation with them [5].

\section{Conclusions}

This study allowed to pinpoint relevant aspects on the profile of crack users from the therapeutic communities in Paraiba and their relations inside of the social, political and economic plan that influence the beginning of use and its capacity to generate dependence.

The users from the therapeutic communities studied presented a socio demographic profile and drug use characteristics similar to the researches conducted in Brazil in different places, being that the majority of the individuals were classified with a high anxiety trace. The majority of the users took part in other treatment modalities before the hospitalization at the community, highlighting the need for development of researches with users in detoxification process in therapeutic communities, aiming to comprehend the deficiencies in existing health services for chemical dependents.

This way, for the effectiveness of the psycho social attention to crack users in detoxification, the therapeutic modalities must provide information to the public power that reinforces the necessity to reformulate the delimitation plan of action strategies that focuses in reducing in the number of hospitalizations. The crack users' characteristic data in this study provide parameters for the chemical dependents assistance, while highlighting the importance of researches in therapeutic communities.

\section{References}

1. Vargens RW, Cruz MS, Santos MA. Comparação entre usuários de crack e de outras drogas em serviço ambulatorial especializado de hospital universitário. Rev. Latino-Am. Enfermagem [online]. 2011; 19:804-812. Available from: http://www.scielo.br/scielo. php?script=sci_arttext\&pid=S0104-11692011000700019.
2. Santos MP, Rocha MR, Araújo RB. O uso da técnica cognitiva substituição por imagem positiva no manejo do craving em dependentes de crack. J. bras. psiquiatr. [online]. 2014; 63(2): 121-126. Available from: http://www.scielo.br/scielo. php?script=sci arttext\&pid=S0047-20852014000200121.

3. Marques ACPR, Ribeiro M, Laranjeira RR, Andrada NC. Abuso e dependência: crack. Rev. Assoc. Med. Bras. 2012; 58(2): 141153. Available from: http://www.scielo.br/scielo.php?script=sci arttext\&pid=S0104-42302012000200008.

4. Kolling NM, Petry MM, Vieira M. Outras abordagens no tratamento da dependência do crack. Rev. bras.ter. cogn. [online]. 2011; 7(1): 7-14. Available from: http://www.rbtc.org. br/detalhe artigo.asp?id=134.

5. Botti NCL, Machado JSA, Tameirão FV. Perfil sociodemográfico e padrão do uso de crack entre usuários em tratamento no Centro de Atenção Psicossocial. Estudos e Pesquisas em Psicologia [online]. 2014; 14(1): 290-303. Available from: http://www.epublicacoes.uerj.br/index.php/revispsi/article/view/10468/8242.

6. Hess ARB. Comorbidades psiquiátricas em dependentes químicos em abstinência em ambiente protegido. Estudos de Psicologia. 2012; 17(1): 171-178. Available from: http:// www.scielo.br/scielo.php?script=sci arttext\&pid $=$ S1413294X2012000100021.

7. Scaduto AA, Barbieri V, Santos MA. Adesão aos Princípios da Comunidade Terapêutica e Processo de Mudança ao Longo do Tratamento. Psicol. cienc. prof. [online]. 2015; 35(3):781-796. Available from: http://www.scielo.br/scielo.php?pid=\$1414$98932015000300781 \&$ script=sci_abstract\&tlng=pt.

8. Perrone PAK. A comunidade terapêutica para recuperação da dependênciadoálcooleoutras drogasnoBrasil:mãoou contramão da reforma psiquiátrica?. Ciênc. Saúdecoletiva [online]. 2014; 19(2): 569-580. Available from: http://www.scielo.br/scielo. php?script=sci arttext\&pid=S1413-81232014000200569.

9. Pacheco AL, Scisleski A. Vivências em uma comunidade terapêutica. Rev. Psicol. Saúde [online]. 2013; 5(2): 165-173. Available from: http://www.gpec.ucdb.br/pssa/index.php/pssa/ article/view/285.

10. Backes DS, Backes MS, Medeiros HMF, Siqueira DF, Pereira SB, Dalcin CB, et al. Oficinas de espiritualidade: alternativa de cuidado para o tratamento integral de dependentes químicos. Rev. esc. enferm. USP [online]. 2012; 46(5): 1254-1259. Available from: $\quad$ http://www.scielo.br/scielo.php?script=sci_arttext\&pid $=$ S0080-62342012000500030.

11. Ribeiro FML, Minayo MCS. Religious therapeutic communities in recovering drug users: the case of Manguinhos, state of Rio de Janeiro, Brazil. Interface (Botucatu). 2015; 19(54): 515-526. Available from: http://www.scielo.br/scielo.php?script=sci artte xt\&pid=S1414-32832015000300515

12. Spielbergert CD, Gorsuch RI, Lushene RE. Manual for the StateTrait Anxiety Inventory. Consulting Psychologists Press, Palo Alto, CA.1970 
13. Biaggio AMB, Natalício L. Manual para o Inventário de Ansiedade Traço-Estado (IDATE). Centro Editor de Psicologia Aplicada (CEPA), Rio de Janeiro. 1979.

14. Horta RL, Horta BL, Rosset AP, Horta CL. Perfil dos usuários de crack que buscam atendimento em Centros de Atenção Psicossocial. Cad. Saúde Pública [online]. 2012; 27(11): 2263-2270. Available from: http://www.scielo.br/scielo. php? script=sci arttext\&pid=S0102-311X2011001100019.

15. Freire SD, Santos PL, Bartolini M, Moraes JFD, Oliveira MS. Intensidade de uso de crack de acordo com a classe econômica de usuários internados na cidade de Porto Alegre/Brasil. J. bras. psiquiatr. [online]. 2012; 61(4): 221-226. Available from: http://www.uniad.org.br/interatividade/artigos/item/17767intensidade-de-uso-de-crack-de-acordo-com-a-classeecon\%C3\%B4mica-de-usu\%C3\%A1rios-internados-nacidade-de-porto-alegre-brasil.

16. Guimarães CF, Santos DVV, Freitas RC, Araújo RB. Perfil do usuário de crack e fatores relacionados à criminalidade em unidade de internação para desintoxicação no Hospital Psiquiátrico São Pedro de Porto Alegre (RS). Rev. psiquiatr. Rio Gd. Sul [online]. 2008; 30(2): 101-108. Available from: http://www.scielo.br/scielo.php?script=sci arttext\&pid =S0101-81082008000300005.

17. Fundação Oswaldo Cruz (FIOCRUZ). Pesquisa Nacional Sobre o Uso de Crack. Carioca Ltda, Rio de Janeiro. 2014.

18. Balbinot AD, Araújo RB. Análise do Perfil de Dependentes em Crack em Internação Hospitalar. Revista Saúde e Pesquisa. 2012; 5(3): 471-480. Available from: http://periodicos.unicesumar. edu.br/index.php/saudpesq/article/view/2424.

Publish in International Archives of Medicine

International Archives of Medicine is an open access journal publishing articles encompassing all aspects of medical science and clinical practice. IAM is considered a megajournal with independent sections on all areas of medicine. IAM is a really international journal with authors and board members from all around the world. The journal is widely indexed and classified Q2 in category Medicine. 